\title{
PENGARUH BIMBINGAN KELOMPOK TEKNIK DISKUSI TERHADAP PERENCANAAN KARIR SISWA
}

\author{
The Effect Of Discussion Engineering Group Guidance On Student Career Planning
}

\author{
Oleh: Nila Istatik Amalia*, Arri Handayani** dan Tri Hartini*** \\ e-mail: nilaamalia587@gmail.com
}

\begin{abstract}
ABSTRAK
Penelitian ini dilatarbelakangi oleh rendahnya perencanaan karir siswa kelas XI MAN 2 Semarang. Hal ini dibuktikan bahwa banyak siswa yang belum mempunyai gambaran tentang perencanaan karir, siswa belum memahami tentang pekerjaan yang nantinya akan diambil, dan masih bingung dalam memilih jurusan di jenjang perguruan tinggi. Tujuan penelitian ini adalah untuk mengetahui pengaruh perencanaan karir sesudah diberikan treatmen melalui bimbingan kelompok dengan teknik diskusi, untuk mengetahui peningkatan dengan teknik diskusi langsung terhadap perencanaan karir siswa. Jenis penelitian ini adalah eksperimen dengan metode penelitian true eksperimental design dengan bentuk pretest-posttest control group design. Sampel yang diambil sebanyak 34 siswa, 10 siswa untuk kelompok eksperimen dan 10 siswa untuk kelompok kontrol dengan menggunakan cluster sampling. Dalam penelitian ini data diperoleh melalui instrumen penelitian berupa skala psikologi perencanaan karir. Jadi dapat disimpulkan bahwa ada pengaruh bimbingan kelompok dengan teknik diskusi terhadap perencanaan karir siswa.
\end{abstract}

\section{Kata Kunci: Bimbingan Kelompok, Teknik Diskusi, Perencanaan Karir}

\section{ABSTRACT}

This research is motivated by the low career planning of students in class XI MAN 2 Semarang. This is evidenced that many students do not have a picture of career planning, students do not understand about the work that will be taken, and are still confused in choosing majors at the university level. The purpose of this study was to determine the effect of career planning after giving treetmen through group guidance with discussion techniques, to find out the improvement with direct discussion techniques on student career planning. This type of research is an experiment with true experimental design research methods in the form of pretest-posttest control group design. Samples taken as many as 34 students, 10 students for the experimental group and 10 students for the control group using cluster sampling. In this study the data obtained through research instruments in the form of career planning psychology scale. So it can be concluded that there is an influence of group guidance with discussion techniques on student career planning.

Key Words: Group Guidance, Discussion Techniques, Career Planning.

Nila Istatik Amalia*, Arri Handayani** dan Tri Hartini***

Bimbingan dan Konseling

Universitas PGRI Semarang 


\section{PENDAHULUAN}

Pendidikan merupakan usaha untuk meningkatkan kemampuan dan mutu kehidupan dalam perkembangan suatu bangsa yang tertuang dalam UndangUndang No. 20 Tahun 2003 tentang system pendidikan Nasional (SISDIKNAS). Pendidikan merupakan asset yang tak ternilai bagi individu dan masyarakat. Pendidikan tidak hanya bidang akademis saja namun menyangkut semua hal yang dapat memberikan wawasan baru, ilmu pengetahuan, serta pengalaman baru bagi individu. Siswa SMA berada pada tingkat perkembangan masa remaja akhir yang hendak memasuki periode dewasa awal seharusnya mampu menguasai tugas-tugas perkembangannya. Hal ini agar tugas perkembangannya berjalan dengan optimal dalam menjalani kehidupan dalam kesehariannya terutama hal karir untuk mencapai masa depannya. Oleh karena itu, siswa diharapkan mampu merencanakan karir untuk ke depannya. Siswa tersebut membutuhkan arahan dan bantuan untuk memilih lanjutan pendidikan ataupun jenis pekerjaansetelah lulus SMA.

Menurut Santrock (2009:26) siswa yang duduk di bangku SMA merupakan usia remaja yang mana merupakan perkembangan transisi antara masa anak dan masa-masa dewasa yang mencakup perubahan biologis, kognitif dan sosioemosional. Memilih jurusan pada saat duduk di bangku SMA maupun memilih jurusan pada saat di bangku perkuliahan merupakan awal bagi siswa untuk merencanakan bakat dan minatnya. Hal ini karena setiap individu memiliki karakteristik/ ciri khas yang berbeda-beda. ditambah perkembangan teknologi yang semakin maju teruntuk siswa dalam dunia pendidikan banyak yang cenderung terpengaruh oleh temannya, kurangnya pendirian, tidak percaya diri, kurangnya mendapatkan dukungan dari orang tua/teman sebaya, kurangnya pengetahuan tentang pekerjaan yang diinginkan, terpaku pada 1 pilihan, tidak mampu mengenali bakat-minat. Banyak siswa yang memandang bahwa sekolah adalah salah satu sekolah formal yang bertujuan untuk mencapai cita-cita kearah pilihan karir yang nantinya diharapkan dapat menunjang masa depan.

Menurut Corey (2006) karir merupakan suatu aspek secara keseluruhan yang ditempuh oleh individu, yang mencakup beberapa jenis pekerjaan yang didukung oleh keprofesionalitasan dan didukung pula dengan pengalaman kerja individu. Oleh karena itu untuk mampu merencanakan dan membuat pilihan karirnya seseorang harus mempunyai pemahaman tentang kemampuan bakat dan minat. Pengenalan karir serta tuntutantuntutan pekerjaan yang ada agar dimasa depan kelak individu dapat merencanakan dan memilih jenis pekerjaan sesuai dengan kemampuannya. Hal tersebut senada dengan pendapat Holland (2007) dimana minat yang menyangkut pekerjaan dan jabatan adalah hasil perpaduan dari kepribadiannya. Sehingga nantinya minat tertentu akan menjadi suatu ciri kepribadian yang berupa ekspresi diri dalam bidang pekerjaan maupun studi akademik (Winkel \& Hastuti, 2004:636). Menurut Holland, begitu seseorang menemukan karirnya maka individu akan dapat menyelesaikan pekerjaannya tersebut dengan baik (Santrock, 2003: 484). 
Bimbingan dan konseling berfungsi dalam dunia pendidika,n dimana membantu siswanya dalam mengarahkan dan memberikan segala informasi mengenai karir dan permasalahan ini. Hal ini penting untuk diperhatikan karena berkaitan dengan kebingungan yang dirasakan oleh siswa MAN 2 Semarang kelas XI MIPA dalam menentukan karirnya. Berdasarkan hasil AKPD yang telah dilakukan sebesar $7,37 \%$ siswa mengalami permasalahan dalam bidang program studi lanjutan dan karir selain itu juga kebanyakandari mereka belum mengenal kepribadiannya, bakat maupun minat, serta kemampuan yang dimilikinya. Adapun pemberian layanan bimbingan klasikal yang kurang maksimal dan dirasa menjenuhkan. Hal tersebut membuat siswa tidak memahami materi yang disampaikian guru bk. Kebanyakan siswa juga masih belum memiliki pendirian teguh, rasa kurang percaya diri rendah dan ikut-ikutan temannya. Oleh karena itu dengan adanya pemberian layanan bimbingan kelompok dengan teknik diskusi diharapkan mampu membuat perubahan dalam karir siswa, yaitu perencanaan karir siswa dapat ditingkatkan sehingga nantinya diharapkan setelah lulus dari SMA tidak mengalami kebingungan lagi dalam memilih program studi lanjutan, maupun jenis pekerjaan yang nantinya ditekuni oleh siswa.

\section{Perencanaan Karir}

Menurut Bangun (2012: 224) perencanaan karir ialah proses dengan penuh pertimbangan atas minat, pengetahuan, dan ketrampilan yang dimiliki karyawan; dan mengidentifikasi tujuan karir yang akan diraih dimasa akan datang. Menurut Kaswan (2014: 78) mendefinisikan perencanaan karir merupakan proses: (a) menjadi sadar terhadap diri sendiri, peluang kendala, pilihan dan konsekuensi, (b) mengidentifikasi tujuan yang terkait dengan karir, (c) memprogram pekerjaan, pendidikan, pengalaman dan pengembangan yang terkait untuk memberi arah timing, dan urutan langkah untuk mencapai tujuan karir khusus. Sedangkan Menurut siagian (2012: 215) menjelaskan perencanaan karir keputusan yang diambil sekarang tentang hal-hal yang akan dikerjakan masa depan, berarti bahwa seseorang yang sudah menetapkan perencanaan karirnya, perlu mengambil langkah-langkah tertentu guna mewujudkan rencana tersebut. Dari pendapat ahli di atas dapat disimpulkan karir ialah usaha serta pengambilan keputusan melalui proses pemikiran yang matang untuk mencapai kehidupan karir sesuai dengan pemahaman diri dan potensi yang dimiliki.

\section{Pengertian Bimbingan Kelompok dengan Teknik Diskusi}

Menurut Romlah (2001:

bimbingan kelompok (Bkp) merupakan proses pemberian bantuan yang diberikan pada individu dalam situasi kelompok. Bimbingan kelompok ditujukan untuk mencegah timbulnya masalah pada siswa dan mengembangkan potensi siswa. Sedangkan menurut Mungin (dalam Narti, 2014: 17) bimbingan kelompok merupakan layanan bimbingan dan konseling yang memungkinkan sejumlah peserta didik secara bersama-sama melalui dinamika kelompok memperoleh berbagai bahan dari narasumber tertentu, (terutama dari Guru Pembimbing) dan atau membahas secara bersama-sama pokok bahasan (topik) tertentu yang berguna untuk menunjang 
pemahaman individu maupun sebagai pelajar, dan untuk pertimbangan dalam pengambilan keputusan dan atau tindakan tertentu.

Menurut Tohirin (2015: 275) teknik diskusi kelompok adalah suatu cara dimana siswa memperoleh kesempatan untuk memecahkan masalah secara bersama-sama. Setiap siswa memperoleh kesempatan untuk mengemukakan pikirannya masing-masing dalam memecahkan suatu masalah. Sedangkan Menurut Majid (2014: 201) teknik diskusi kelas atau diskusi kelompok adalah proses pemecahan masalah yang dilakukan oleh seluruh anggota kelas sebagai peserta didik. Dimana semua permasalahan bisa dicari jalan keluarnya melalui diskusi kelompok.

Dapat diambil kesimpulan dari berbagai pendapat para ahli di atas. Teknik diskusi kelompok merupakan sebuah cara penyajian bahan pelajaran dimana guru memberi kesempatan kepada para anggota kelompok untuk mengadakan perbincangan ilmiah guna mengumpulkan pendapat, membuat kesimpulan, atau menyusun berbagai alternatif pemecahan atas suatu masalah yang sedang dibahas.

\section{Tujuan Bimbingan kelompok dengan Teknik Diskusi}

Tujuan layanan bimbingan kelompok menurut Prayitno (dalam Narti, 2014: 26) mengemukakan bahwa secara umum tujuan layanan bimbingan kelompok ialah untuk mengembangkan kemampuan bersosialisasi, khususnya kemampuan berkomunikasi kondisi dan proses berperasaan, berfikir, berpresepsi, dan berwawasan yang terarah, luwes, dan luas serta dinamis, maka kemampuan berkomunikasi, bersosialisasi dan bersikap dapat dikebangkan. Beberapa tujuan dari teknik diskusi Abimanyu, dkk (dalam Thaem 2012: 65) (a) Memecahkan materi pembelajaran yang berupa masalah problematik yang sukar dilakukan oleh siswa serta perorangan, mengembangkan keberanian siswa mengemukakan pendapat, (c) mengembangkan sikap toleran terhadap yang berbeda, (d) melatih siswa mengembangkan sikap demokratis, keterampilan, berkomunikasi, mengeluarkan pendapat, menafsirkan dan menyimpulkan pendapat, (e) melatih dan membentuk kestabilan social-emosional.

Dari penjelasan di atas dapat disimpulkan bahwa dalam tujuan layanan bimbingan kelompok menggunakan teknik diskusi adalah membahas topik-topik tertentu, melatih siswa untu menerima pendapat orang lain, memiliki sikap tenggang rasa, mengendalikan emosi dan memberikan keakraban pada anggota kelompok yang satu dengan anggota kelompok lainnya. Serta menyelesaikan suatu permasalahan yang dapat dibahas dan dicari penyelesaian permasalahannya secara bersama-sama.

\section{METODE PENELITIAN}

Dalam penelitian ini menggunakan metode kuantitatif eksperimen dimana penelitian ini untuk mengetahui pengaruh dari suatu treatment yang diberikan kepada subjek. Menurut Sugiyono (2013:107) metode penelitian merupakan suatu metode penelitian yang digunakan untuk mengetahui suatu pengaruh perlakuan tertentu terhadap yang lain . Pendekatan kuantitatif untuk menjawab segala permasalahan yang ada (Sugiyono, 
2013:50). Penelitian dengan judul pengaruh layanan bimbingan kelompok dengan teknik diskusi untuk meningkatkan perencanaan karir siswa kelas XI MAN 2 Semarang dilaksanakan di MAN 2Semarang. Waktu penelitian pada bulan Juli - September 2019 pada semester I tahun pelajaran 2019/2020. Dalam penelitian ini proses ekperimen pengumpulan data dapat dibagi menjadi tiga tahap yaitu tahap persiapan, tahap pelaksanaan dan tahap pengakhiran. Dimana setiap tahap tersebut peneliti memuat beberapa langkah-langkah sebagai berikut :

\section{Persiapan}

a. Subjek penelitian yang akan diteliti adalah peserta didik kelas XI yang terdiri dari kelas XI MIPA 1, XI MIPA 2, XI MIPA 3, XI MIPA 4, XI MIPA 5. Dari jumlah lima kelas tersebut terpilih 2 kelas menggunakan cluster random sampling, yaitu teknik sampling daerah digunakan untuk menentukan sampel bila obyek yang akan diteliti atau sumber data sangat luas (Sugiyono, 2017:121). Satu kelas untuk try out yaitu kelas XI MIPA 1 dan satu kelas yang menjadi kelompok eksperimen dan kelompok kontrol, yaitu kelas XI MIPA 2.

b. Melakukan try out skala perencanaan karir siswa kelas XI MIPA MAN 2 Semarang yang berjumlah 34 siswa untuk menguji validitas dan reliabilitas.

c. Melakukan pre-test terhadap kelas XI MIPA 2 dengan jumlah 33 siswa. Selanjutnya kelas yang diberi pretest akan dipilih sebagai kelompok eksperimen 10 siswa dan kelompok kontrol 10 siswa. kelompok kontrol dan kelompok eskperimen menggunakan simple random sampling. Dikatakan simple (sederhana) karena pengambilan anggota sampel dari populasi dilakukan secara acak tanpa memperhatikan strata yang ada dalam populasi itu (Sugiyono, 2015:120)

d. Berdasarkan data pre-test terhadap kelas XI MIPA 1

2. Pelaksanaan eksperimen

a. Setelah menentukan 10 siswa dari kelas XI MIPA 2, selanjutnya menentukan kelompok eksperimen dan kelompok kontrol kelas tersebut. Dimana kelas XI MIPA 2 sebagai kelompok eksperimen dan kelompok kontrol.

b. Sesudah ditetapkan kelompok kontrol dan kelompok eksperimen, kemudian kelompok kontrol diberikan tindakan oleh guru BK dan kelompok eksperimen diberikan layanan bimbingan kelompok dengan teknik diskusi oleh peneliti.

c. Treatment dilaksanakan terhadap kelompok eksperimen sebanyak 5 kali. Sedangkan kelompok kontrol diberikan layanan oleh guru BK.

\section{Akhir Eksperimen}

a. Sesudah mendapatkan perlakuan, maka pada kelompok eksperimen dan kelompok kontrol diberikan post-test, guna mengetahui adakah perbedaan antara kelompok kontrol dan kelompok eksperimen.

b. Selanjutnya peneliti melakukan analisis menggunakan uji- $t$ untuk mengetahui pengaruh layanan 
bimbingan kelompok dengan teknik diskusi.

\section{HASIL PENELITIAN DAN PEMBAHASAN}

Berdasarkan hasil perhitungan uji hipotesis diperoleh $t_{\text {hitung }}=6,012$. Selanjutnya dikonsultasikan dengan $t_{\text {tabel }}$ taraf signifikansi 5\% (0.05) yaitu 2,101. Hal tersebut menunjukkan bahwa $t_{\text {hitung }}=$ $6,012 \geq t_{\text {tabel }}=2,101$. Atas dasar perhitungan tersebut maka hipotesis (Ho) yang berbunyi “ ada pengaruh layanan bimbingan kelompok dengan teknik diskusi terhadap perencanaan karir siswa kelas XI MAN 2 Semarang" diterima kebenarannya pada taraf signifikansi $5 \%$. Oleh karena itu hipotesis yang berbunyi "ada pengaruh bimbingan kelompok dengan teknik diskusi terhadap perencanaan karir siswa kelas XIMAN 2 Semarang" diterima kebenarannya.

Analisis hasil pre-test antara kelompok eksperimen dan kelompok kontrol menunjukkan bahwa tidak ada perbedaan yang signifikansi antara kelompok eksperimen dan kelompok kontrol. Rata-rata kelompok eksperimen sebesar 71,6 menjadi 72,9 terjadi peningkatan 93,0. Sedangkan pada kelompok control dari 68,5 menjadi 69,0 terjadi penimgkatan sebesar 0,8. Selisih antara kelompok eksperimen dan kelompok control yaitu 8,3. Hasil analisis data menunjukkan bahwa ada perbedaan antara kelompok eksperimen yang diberikan treatment berupa layanan bimbingan kelompok dengan menggunakan teknik diskusi, sedangkan kelompok kontrol tidak diberikan treatment.
Penelitian ini membahas mengenai perencanaan karir siswa, hal ini ditunjukan dengan rendahnya pengetahuan tentang perencanaan karir. Permasalahan yang sering dialami siswa diantaranya masih belum mempunyai gambaran tentang perencanaa karir, belum mempunyai citacita, belum memahami tentang pekerjaan yang nantinya akan diambil, dan masih bingung dalam memilih jurusan di jenjang perguruan tinggi, maka siswa perlu diberikan arahan tentang pilihan karir. Untuk meningkatkan perencanaan karir siswa maka digunakan layanan bimbingan kelompok dengan teknik diskusi

Nurihsan (2014:23) menyatakan bimbingan kelompok merupakan bantuan terhadap individu yang dilaksanakan dalam situasi kelompok. Bimbingan kelompok dapat berupa penyampaian informasi ataupun aktivitas kelompok membahas masalah-masalah pendidikan, pekerjaan, pribadi dan sosial. Pemberian. informasi dalam bimbingan kelompok terutama dimaksudkan untuk meningkatkan pemahaman tentang kenyataan, aturanaturan dalam kehidupan, cara-cara yang yang dilakukan untuk menyelesaikan tugas. Bimbingan melalui aktivitas kelompok lebih efektif karena selain peran individu lebih aktif, juga memungkinkan terjadinya pertukaran pemikiran, pengalaman, rencana dan penyelesaian masalah. Menurut Roestiyah (2012: 5) teknik diskusi adalah proses interaksi antara dua orang atau lebih individu yang terlibat, saling tukar menukar pengalaman, informasi, memecahkan masalah, dapat terjadi juga semuanya aktif tidak ada yang pasif sebagai pendengar saja. Berdasarkan definisi tersebut menunjukkan bahwa teknik diskusi dapat digunakan untuk 
membantu individu agar memiliki perencanaan karir yang sesuai, mampu merencanakan karirnya dengan baik, termasuk di dalamnya membantu individu agar mampu menyelesaikan permasalahan karirnya entah bekerja atau melanjutkan keperguruan tinggi.

Dengan diberikannya layanan bimbingan kelompok dengan teknik diskusi, membuat siswa belajar bukan hanya dengan cara melakukan penilaian diri yang kemudian akan membawa dampak pada setiap usaha maupun tindakan yang dilakukan. Tetapi melihat sebuah model yang sesuai dengan dirinya akan membantu siswa dalam melakukan penilaian diri. Di dalam penelitian ini indikator yang tertinggi adalah mampu merencanakan langkah-langkah perencanaan karir. Hal tersebut membuat siswa bisa lebih memahami tentang perencanaan karirnya yang sesuai dan membuat siswa mempunyai gambaran yang baik terkait perencanaan karir masadepannya. Hal ini didukung penelitian Priyatno (2016: 51) fakta menunjukkan bahwa pemahaman tentang perencanaan karir siswa, berpengaruh untuk melanjutkan ke jenjang perguruan tinggi dengan diterapkan layanan bimbingan kelompok dengan teknik diskusi kelompok. Dengan harapan siswa bisa bertukar pikiran, menggali dan mencari informasi tentang perencanaan karir siswa. Pemberian treatment dilaksanakan sebanyak 5 pertemuan, dalam treatment anggota kelompok melaksanakan diskusi sesuai dengan topik yang dibahas.

Dari uraian di atas dapat disimpulkan bahwa bimbingan kelompok dengan teknik diskusi ada pengaruh terhadap perencanaan karir siswa kelas XI MAN 2 Semarang.

\section{KESIMPULAN DAN SARAN}

Berdasarkan hasil perhitungan analisis data post-test diketahui skor ratarata kelompok eksperimen etika pergaulan siswa menjadi meningkat dari 71,5 dan menjadi 93,5 setelah dilaksanakannya treatment. Bimbingan kelompok dengan teknik diskusi berpengaruh terhadap perencanaan karir siswa, hal ini dibuktikan dengan uji $t$ yang memperoleh hasil sebesar $t_{\text {hitung }}$ sebesar 6,012 sementara $t_{\text {tabel }}$ dengan $\mathrm{db}(\mathrm{n} 1+\mathrm{n} 2)-2=(10+10)-2=18$ dengan taraf signifikansi 5\% (0.05) sebesar 2,101. Karena jumlah $t_{\text {hitung }}>t_{\text {tabel }}$ maka Ho ditolak dan $\mathrm{Ha}$ diterima, sehingga hipotesisnya (Ha) berbunyi "ada pengaruh layanan bimbingan kelompok dengan teknik diskusi terhadap perencanaan karir siswa kelas XI MIPA MAN 2 Semarang”. Teknik diskusi itu dapat diterima dengan optimal sehingga dapat meningkatkan perencanaan karir siswa.

Saran yang dapat diberikan adalah (1) diharapkan dapat memberikan layanan bimbingan kelompok dengan teknik diskusi kelompok untuk membantu siswa dalam merencanakan karir dimasa depan kelak, (2) hasil penelitian ini diharapkan dapat menjadi masukan untuk bisa meningkatkan perencanaan karir siswa dalam pelaksanaan bimbingan dan konseling di MAN 2 Semarang, dan (3) diharapkan peneliti lain yang ingin menggunakan penelitian serupa dapat menggunakan jam istirahat atau jam pulang sekolah agar tidak mengganggu jam pelajaran lainnya.

\section{DAFTAR PUSTAKA}

Arikunto, Suharsini.2009. Prosedur 
Penelitian Suatu Pendekatan

Praktik. Jakarta: Rineka Cipta.

Bangun, Wicaksono. 2002. Manajemen

Sumber Daya Manusia. Jakarta:

Erlangga.

Corey, Gerald. 2005. Teori dan Praktik

Dari Konseling \& Psikoterapi.

Jakarta; ERESCO.

Kaswan, 2014. Career Developmen

(Pengembangan Karir Untuk

Mencapai Kesuksesan dan

Kepuasan) Bandung: Alfabeta.

Majid, Abdul. 2014. Srategi

Pembelajaran, Bandung: Remaja

Rosdakarya.

Nurihsan, Achmad Juantika. 2014.

Bimbingan dan Konseling dalam

berbagai latar kehidupan. Bandung:

PT Refika Aditama

Priyatno, Tovik. 2016. Upaya

Meningkatkan Pemahaman

Eksplorasi Karir Melalui Layanan

Bimbingan Kelompok Dengan

Teknik Diskusi Kelompok. Jurnal

Psikopedagogia. Volume 5. No 1.

Putra, Chandra Anugrah. 2016. Pengaruh Strategi Pembelajaran Berbasis Proyek Perancangan dan Kecerdasan Logik-Matematik Terhadap Kompetensi Merancang Web. Jurnal Teknologi Pendidikan, 18(2):90-101.

Riadin, Agung, dkk. 2017. Karakteristik Anak Berkebutuhan Khusus di Sekolah Dasar Negeri (Inklusi) di Kota Palangka Raya. Anterior Jurnal, 17(1):22-27.

Romlah, Tatiek. 2001. Teori dan Praktik

Bimbingan Kelompok. Surabaya:

Universitas Negeri Malang.

Safithry, Esty Aryani \& Niky Anita. 2019.

Konseling Kelompok Dengan
Teknik Self Management Untuk Menurunkan Prasangka Sosial Peserta Didik. Suluh: Jurnal Bimbingan Dan Konseling, 4(2):3341.

Santrock, John W. 2009. Psikologi Pendidikan Jakarta: Salemba Humanika

Setiawan, M Andi. 2015. Model konseling kelompok dengan teknik problem solving untuk meningkatkan selfefficacy akademik siswa. Jurnal Bimbingan Konseling 4(1).

Siagian, Sondang. 2012. Manajemen Sumber Daya Manusia. Jakarta: Bumi Aksara.

Sugiyono. 2013. Metode Penelitian Pendidikan (Pendekatan Kuantitatif, Kualitatif, dan R\&D). Bangun: Alfabeta.

Thaem, Albinus. 2012. Metode Diskusi Dalam Pembelajaran Struktur Tumbuhan di kelas IV Sekolah Dasar Negeri 10 Melayu Rakyat Ketapang. Pontianak: Universitas Tanjungpura

Tohirin, 2015. Bimbingan dan Konseling di Sekolah dan Madrasah (Berbasis Intelegensi). Jakarta: PT. Raja Grafindo.

Winkel, W. S dan MM Sri Hastuti 2008. Bimbingan dan Konseling Kelompok. Jakarta: Rineka Cipta.

Nila Istatik Amalia*, Arri Handayani** dan Tri Hartini****

Bimbingan dan Konseling

Universitas PGRI Semarang 